\title{
Vitamin D Levels in Patients with and without Acne and Its Relation to Acne Severity: A Case-Control Study [Corrigendum]
}

\author{
Alhetheli G, Elneam AIA, Alsenaid A, Al-Dhubaibi \\ M. Clin Cosmet Investig Dermatol. 2020;13:759-765.
}

The authors have advised the author list on page 759 is incorrect. The author "Mohammed Al-Dhubaibi" should read "Mohammed Saleh Al-Dhubabi".

\section{Publish your work in this journal}

Clinical, Cosmetic and Investigational Dermatology is an international, peer-reviewed, open access, online journal that focuses on the latest clinical and experimental research in all aspects of skin disease and cosmetic interventions. This journal is indexed on CAS.
The manuscript management system is completely online and includes a very quick and fair peer-review system, which is all easy to use. Visit http://www.dovepress.com/testimonials.php to read real quotes from published authors. 